American Journal of Applied Sciences 9 (7): 1014-1019, 2012

ISSN 1546-9239

(C) 2012 Science Publications

\title{
Determination of Heavy Metals and Other Elements in Artisanal Gold Mining Soils
}

\author{
${ }^{1}$ Girigisu, S., ${ }^{2}$ I.G.E. Ibeanu, ${ }^{2}$ D.J. Adeyemo and ${ }^{3}$ S. Okoh \\ ${ }^{1}$ Department of Physics, School of Science Education, \\ Federal College of Education (Technical) Gusau, Nigeria \\ ${ }^{2}$ Health Physics and Radiation Biophysics Section, \\ ${ }^{3}$ Materials Science and Development Section, \\ Center for Energy Research and Training, Ahmadu Bello University, Zaria, Nigeria
}

\begin{abstract}
Problem statement: The possible exposure of heavy elements to life as a result of artisanal gold mining activities can be of great concern because of its associated effect on health. Approach: Soil samples from the artisanal gold mining sites of Awwal and Bagega villages in Kebbi and Zamfara states of Nigeria were collected and analyzed for heavy and other elements by X-Ray Fluorescence (XRF) technique. Ten of the element analyses are presented in this study, based on their toxicity levels. Results: Four of the ten elements ( $\mathrm{Pb}, \mathrm{Si}, \mathrm{Rb}$ and $\mathrm{Fe}$ ) showed relatively high concentrations. Two of these four elements presented, ( $\mathrm{Si}$ and $\mathrm{Pb}$ ) may pose latent and immediate hazards to health. Respiratory crystalline silica is the major element constituent of the ever-wellpronounced mining dusts of the two sites. Its form of occurrence portends irreversible health problem called silicosis and is well linked to cancer forming properties; both of which develop through latency periods. $\mathrm{Pb}$ at whatever concentration portends both immediate and long term hazards to women and children at the greatest risks of exposures. Conclusion: Based on the results presented, there exist a possibility of an immediate and long term health risks associated with the artisanal gold mining exercises in the two sites studied if the said uncoordinated and unprofessional activities of the miners are left unchecked.
\end{abstract}

Key words: Artisanal Gold mining, heavy elements, contamination, poisoning, silicosis, carcinogenesis

\section{INTRODUCTION}

Mining of minerals such as gold is found to be one of the major routes of exposure of life to heavy metals and other elements whose toxicity have been documented throughout history. It has been reported that Greek and Roman physicians diagnosed symptoms of acute lead poisoning long before toxicology even became a science (Jerome, 1996).

The heavy metals are hazardous to life and the mining exercise is also environmentally damaging (WR, 1998). The presence of these heavy metals and other elements excavated can reside in the environment for hundreds of years. The presence of these metals in soil has been reported to affect the quality of food grown, groundwater quality, micro-organisms activity and plant growth (Popescu et al., 2009).

The activities that generate concentration of these heavy metals and other elements in the soil can have a serious effect on the affected communities. The effects include toxicological and environmental degradation. It is now known that exposure to some heavy metals has been linked with developmental retardation, various cancers, kidney damage and even death. Exposure to high levels of mercury, gold and lead has been reported to be associated with the development of autoimmunity in which the system's needed immune system begins to attack the cells it should protect, mistaking them for foreign bodies. And, that the autoimmunity can lead to the development of diseases of the circulatory or central nervous system (Glover-Kerkvliet, 1995).

Despite the known health effects, it is also known that mercury is still extensively used in gold mining in many parts of the world, including our research sites.

Artisanal mining is a process that is associated with generation of dust. The uncoordinated, uneducated and unprotected miners take in this dust laden with crystalline silica which is known to be a major soil forming component. The inhalation of this crystalline silica has been reported to initially cause respiratory irritation and an inflammatory reaction in the lungs (Vallyathan et al., 1995). Acute exposures to high

Corresponding Author: D.J. Adeyemo, Health Physics and Radiation Bio-Physics Section, Center for Energy Research and Training, Ahmadu Bello University, Zaria, Nigeria 
concentrations cause cough, lipoproteinosis (Chronic Toxicity, 2005). In a report on the hazards of exposure to crystalline silica, it was stated that, NIH (1997) reported that their studies from many different work environments suggest that "exposure to working environments contaminated with silica at dust levels that appear not to cause roentgenographically visible simple silicosis can cause chronic airflow limitation and/or mucus hypersecretion and/or pathological emphysema". In the result of Hnizdo and Vallyathan (2003), they concluded that "chronic levels of silica dust that do not cause disabling silicosis may cause the development of chronic bronchitis, emphysema and/or small airways disease that can lead to airflow obstruction, even in the absence of radiological silicosis" (Oxman et al., 1993; Park et al., 2002; Hnizdo and Vallyathan, 2003; Balmes et al., 2003)

\section{MATERIALS AND METHODS}

Soil sample collection: An initial survey was undertaken of the two main sites to map out in each case the three mining stages where sampling was to be carried out. The two study sites are: Hawwal, located on the southern part of Kebbi state between longitudes $4^{\circ} 45^{\prime}$ and $4^{\circ} 50^{\prime}$ East of the prime meridian and latitudes $11^{\circ} 35^{\prime}$, and $11^{\circ} 40^{\prime}$ North of the equator and Bagega, which is a settlement on the North-Eastern part of Hawwal, though in Zamfara State. Baggage is on longitude $6^{\circ} 00^{\prime}$ East of the prime meridian and latitudes $11^{\circ} 43^{\prime}$ to $11^{\circ} 50^{\prime}$ North of the equator.

About $500 \mathrm{~g}$ of soil from each spot was collected. All the samples were mixed thoroughly as a composite sample representative of the sampling stages. They were transferred into polythene bags, labeled and doublebagged to avoid cross-contamination in each case.

Procedure for analysis of samples: $0.5 \mathrm{~g}$ of each sample for analysis was weighed and grounded in an agate mortar and a binder (PVC dissolved in Toluene) was added to each sample, carefully mixed and pressed in a hydraulic press into a pellet.

A compact Mini Pal 4 energy dispersive x-ray fluorescence spectrometer (PW4030) was used for the elemental analysis. The system is controlled by a computer running the dedicated Mini pal analytic software and the microprocessor controls the analytical instrument which was designed for the detection and measurement of elements in a sample from sodium to uranium. The pellets were loaded in the sample chamber of the spectrometer and voltage (30kv max.) and a current ( $1 \mathrm{~mA}$ max.) were applied to produce the $\mathrm{x}$-rays to excite the samples for a preset time of 10 minutes each. The spectra of the samples were then analyzed to determine the concentrations of the elements in the samples.

\section{RESULTS}

A total of ten (10) elements that were determined are presented in this study. Table 1-6 and correspondingly, Fig. 1-6 represent the analytical results for the two sites that were investigated. Table 7a and $7 \mathrm{~b}$ on the other hand, give the comparative summary of the elemental assessments. The benchmark by regulatory bodies are presented in Table 8 .

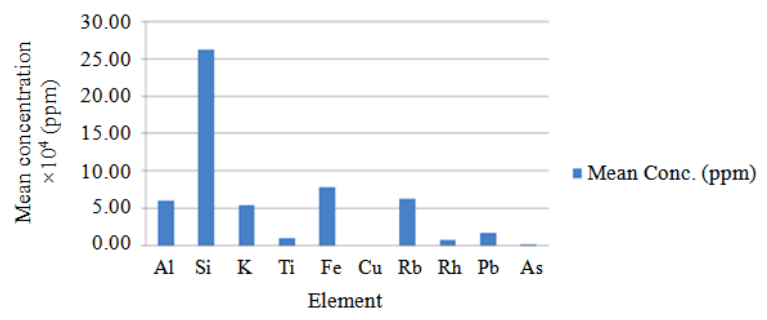

Fig. 1: Chart of result for Awwal mine zone

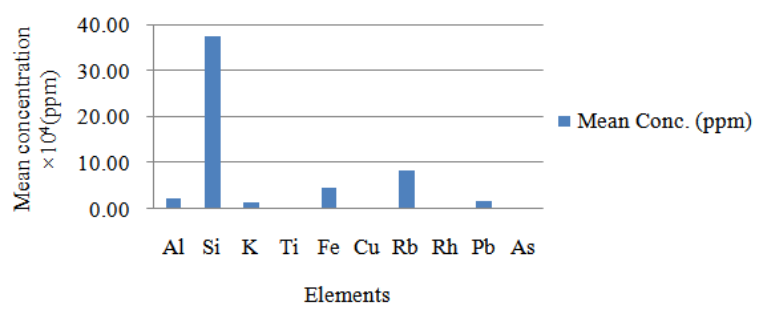

Fig. 2: Chart of result for Awwal mills zone

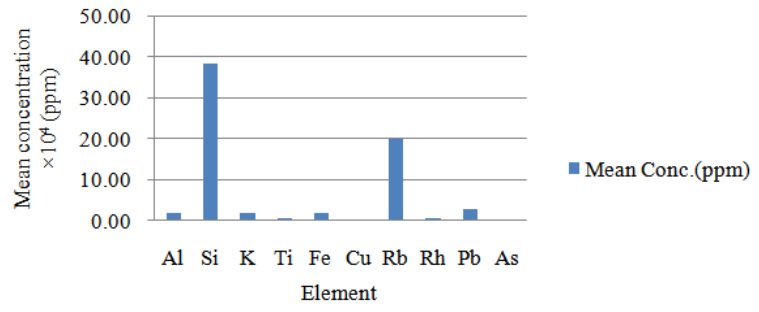

Fig. 3: Chart of result for Awwal sedimentation zone

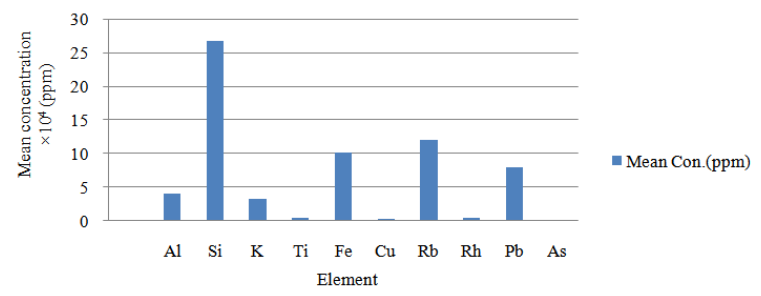

Fig. 4: Chart of result for Bagega mine zone 1015 
Am. J. Applied Sci., 9 (7): 1014-1019, 2012

Table 1: Result for Awwal mines zone

\begin{tabular}{|c|c|c|c|c|c|c|c|c|c|c|}
\hline \multirow[b]{2}{*}{ Element } & \multicolumn{10}{|c|}{$\begin{array}{l}\text { AWWAL: KEBBI state } \\
\text { Unit 1: Mining café samples } \\
\text { Sample code/element concentration } \times 10^{4}(\mathrm{ppm})\end{array}$} \\
\hline & $\mathrm{C}_{1} \mathrm{~S}_{1}$ & $\mathrm{C}_{1} \mathrm{~S}_{2}$ & $\mathrm{C}_{2} \mathrm{~S}_{1}$ & $\mathrm{C}_{2} \mathrm{~S}_{2}$ & $\mathrm{C}_{3} \mathrm{~S}_{1}$ & $\mathrm{C}_{3} \mathrm{~S}_{2}$ & $\mathrm{C}_{4} \mathrm{~S}_{1}$ & Mean & Max. & Range \\
\hline$\overline{\mathrm{Al}}$ & 7.04 & 6.51 & 4.39 & 6.24 & 6.56 & 6.30 & 5.13 & 6.02 & 7.04 & $4.39-7.04$ \\
\hline $\mathrm{Si}$ & 17.71 & 32.14 & 32.29 & 27.61 & 18.96 & 25.78 & 29.75 & 26.32 & 32.29 & $17.71-32.29$ \\
\hline $\mathrm{K}$ & 7.20 & 5.10 & 3.31 & 4.65 & 8.55 & 6.56 & 2.84 & 5.46 & 8.55 & $2.84-8.55$ \\
\hline $\mathrm{Ti}$ & 1.70 & 0.36 & 0.53 & 0.69 & 1.95 & 0.93 & 0.63 & 0.97 & 1.95 & $0.53-1.95$ \\
\hline $\mathrm{Fe}$ & 14.65 & 0.06 & 6.11 & 4.33 & 11.40 & 5.77 & 12.25 & 7.80 & 14.65 & $0.06-14.65$ \\
\hline $\mathrm{Cu}$ & 0.07 & 0.03 & 0.10 & 0.04 & 0.06 & 0.07 & 0.07 & 0.06 & 1.10 & $0.03-0.10$ \\
\hline $\mathrm{Rb}$ & 10.97 & N.D & N.D & 11.88 & 11.88 & 9.14 & N.D & 5.27 & 11.88 & $6.27-11.88$ \\
\hline $\mathrm{Rh}$ & 0.71 & 0.32 & 0.81 & 0.38 & 0.78 & 1.14 & 0.97 & 0.73 & 1.14 & $0.32-1.14$ \\
\hline $\mathrm{Pb}$ & 2.13 & 1.11 & 1.58 & 1.67 & 2.13 & 1.58 & 2.04 & 1.75 & 2.13 & $1.11-2.13$ \\
\hline As & 0.17 & 0.07 & 0.37 & 0.23 & 0.21 & 0.13 & 0.15 & 0.19 & 0.37 & $0.07-0.37$ \\
\hline
\end{tabular}

Table 2: Result for Awwal mills zone

Unit 2: Mining shed samples

Sample code/concentration $\times 10^{4}(\mathrm{ppm})$

\begin{tabular}{lccccccccc} 
Element & $\mathrm{M}_{1} \mathrm{~S}_{1}$ & $\mathrm{M}_{1} \mathrm{~S}_{2}$ & $\mathrm{M}_{2} \mathrm{~S}_{1}$ & $\mathrm{M}_{2} \mathrm{~S}_{2}$ & $\mathrm{M}_{3} \mathrm{~S}_{1}$ & $\mathrm{M}_{3} \mathrm{~S}_{2}$ & Mean & Max. & Range \\
\hline $\mathrm{Al}$ & 2.80 & 2.80 & 2.49 & 2.38 & 1.32 & 2.59 & 0.40 & 2.80 & $1.32-2.8$ \\
$\mathrm{Si}$ & 39.19 & 39.28 & 37.79 & 35.64 & 34.38 & 39.19 & 37.58 & 39.28 & $34.38-39.28$ \\
$\mathrm{~K}$ & 1.83 & 1.68 & 1.49 & 1.48 & 0.97 & 1.47 & 1.49 & 1.83 & $0.97-1.83$ \\
$\mathrm{Ti}$ & 0.17 & 0.17 & 0.14 & 0.17 & 0.20 & 0.15 & 0.17 & 0.20 & $0.14-0.2$ \\
$\mathrm{Fe}$ & 2.77 & 2.79 & 5.23 & 8.21 & 4.91 & 0.53 & 4.57 & 8.21 & $2.77-8.21$ \\
$\mathrm{Cu}$ & 0.09 & 0.08 & 0.09 & 0.10 & 0.11 & 0.04 & 0.09 & 0.11 & $0.04-0.11$ \\
$\mathrm{Rb}$ & $\mathrm{N} . \mathrm{D}$ & $\mathrm{N} . \mathrm{D}$ & $\mathrm{N} . \mathrm{D}$ & $\mathrm{N} . \mathrm{D}$ & 8.59 & $\mathrm{~N} . \mathrm{D}$ & 8.59 & 8.59 & 0.8 .59 \\
$\mathrm{Rh}$ & 0.43 & 0.35 & 0.32 & 0.53 & 0.77 & 0.28 & 0.45 & 0.77 & $0.28-0.77$ \\
$\mathrm{~Pb}$ & 0.19 & 1.86 & 2.50 & 2.98 & 2.50 & 0.19 & 1.70 & 2.98 & $0.19-2.98$ \\
$\mathrm{As}$ & 0.37 & 0.30 & 0.36 & 0.55 & 0.23 & 0.07 & 0.31 & 0.55 & $0.07-0.55$ \\
\hline
\end{tabular}

Table 3: Result for Awwal sedimentation zone

\begin{tabular}{|c|c|c|c|c|c|c|c|c|c|}
\hline \multirow[b]{2}{*}{ Element } & \multicolumn{9}{|c|}{$\begin{array}{l}\text { Unit 3: Sedimentation zone samples } \\
\text { Sample code/concentration } \times 10^{4}(\mathrm{ppm})\end{array}$} \\
\hline & $\mathrm{T}_{1} \mathrm{~S}_{1}$ & $\mathrm{~T}_{1} \mathrm{~S}_{2}$ & $\mathrm{~T}_{2} \mathrm{~S}_{1}$ & $\mathrm{~T}_{2} \mathrm{~S}_{2}$ & $\mathrm{~T}_{3} \mathrm{~S}_{1}$ & $\mathrm{~T}_{3} \mathrm{~S}_{2}$ & Mean & Max. & Range \\
\hline$\overline{\mathrm{Al}}$ & 1.18 & 1.80 & 0.38 & 2.54 & 0.85 & 0.53 & 1.88 & 2.85 & $0.53-2.85$ \\
\hline $\mathrm{Si}$ & 41.43 & 42.04 & 40.12 & 38.86 & 40.68 & 27.28 & 38.40 & 42.04 & $27.28-42.04$ \\
\hline K & 2.16 & 1.04 & 2.39 & 3.34 & 1.29 & N.D & 2.04 & 3.34 & $1.04-3.34$ \\
\hline $\mathrm{Ti}$ & 0.08 & 0.27 & 0.50 & 2.88 & 0.12 & 0.09 & 0.66 & 2.88 & $0.08-2.88$ \\
\hline $\mathrm{Fe}$ & 0.25 & 1.61 & 2.65 & 2.61 & 1.90 & 2.65 & 2.11 & 2.65 & $1.25-2.65$ \\
\hline $\mathrm{Cu}$ & 0.05 & 0.02 & 0.03 & 0.06 & 0.03 & 0.08 & 0.05 & 0.08 & $0.02-0.08$ \\
\hline $\mathrm{Rb}$ & N.D & N.D & N.D & N.D & N.D & 20.11 & 20.11 & 20.11 & $0-20.11$ \\
\hline $\mathrm{Rh}$ & 0.97 & 0.41 & 0.48 & 0.81 & N.D & 0.66 & 0.67 & 0.97 & $0.41-0.97$ \\
\hline $\mathrm{Pb}$ & N.D & 0.58 & N.D & N.D & 1.02 & 2.69 & 0.86 & 2.86 & $1.02-2.86$ \\
\hline As & N.D & N.D & N.D & N.D & 0.02 & 0.16 & 0.09 & 0.16 & $0.02-0.16$ \\
\hline
\end{tabular}

Table 4: Result for Baggage Mine zone

\begin{tabular}{|c|c|c|c|c|c|c|c|c|c|c|c|c|c|}
\hline \multirow[b]{2}{*}{ Elements } & \multicolumn{13}{|c|}{$\begin{array}{l}\text { Baggage/Sunke: Zamfara state } \\
\text { Unit 1: Mining zone samples } \\
\text { Sample code/element concentration } \times 10^{4}(\mathrm{ppm})\end{array}$} \\
\hline & $\mathrm{C}_{2} \mathrm{~S}_{2}$ & $\mathrm{C}_{2} \mathrm{~S}_{3}$ & $\mathrm{C}_{\mathrm{I}} \mathrm{S}_{\mathrm{I}} \mathrm{G}$ & $\mathrm{C}_{\mathrm{I}} \mathrm{S}_{\mathrm{I}}$ & $\mathrm{C}_{1} \mathrm{~S}_{2}$ & $\mathrm{C}_{3} \mathrm{~S}_{1}$ & $\mathrm{C}_{3} \mathrm{~S}_{2}$ & $\mathrm{C}_{3} \mathrm{~S}_{3}$ & $\mathrm{C}_{3} \mathrm{~S}_{4} \mathrm{G}$ & $\mathrm{C}_{4} \mathrm{~S}_{3}$ & Mean & Max. & Range \\
\hline$\overline{\mathrm{Al}}$ & 5.24 & 7.41 & 0.37 & 5.29 & 4.13 & 3.33 & 2.33 & 5.82 & 1.32 & 6.35 & 4.16 & 7.41 & $0.37-7.41$ \\
\hline $\mathrm{Si}$ & 14.95 & 27.84 & 33.16 & 33.68 & 29.61 & 33.07 & 17.28 & 26.48 & 23.82 & 28.82 & 26.87 & 33.68 & $14.95-33.68$ \\
\hline $\mathrm{K}$ & 5.54 & 5.58 & N.D & 4.21 & 2.08 & 1.42 & 2.49 & 3.35 & 0.75 & 3.69 & 3.23 & 5.58 & $1.42-5.58$ \\
\hline $\mathrm{Ti}$ & 0.66 & 0.78 & N.D & 0.33 & 0.17 & 0.32 & 0.60 & 0.78 & 0.05 & 0.45 & 0.46 & 0.78 & $0.05-0.78$ \\
\hline $\mathrm{Fe}$ & 15.58 & 8.25 & 7.90 & 6.30 & 8.25 & 5.53 & 17.47 & 11.81 & 8.11 & 12.79 & 10.20 & 17.47 & $6.3-17.47$ \\
\hline $\mathrm{Cu}$ & 0.45 & 0.27 & 0.53 & 0.20 & 0.83 & 0.20 & 0.47 & 0.34 & 0.37 & 0.13 & 0.38 & 0.83 & $0.2-0.83$ \\
\hline $\mathrm{Rb}$ & 8.14 & N.D & 11.88 & N.D & N.D & N.D & 16.45 & N.D & N.D & N.D & 12.16 & 16.45 & $8.14-11.88$ \\
\hline $\mathrm{Rh}$ & 0.16 & 0.16 & 0.41 & N.D & N.D & N.D & 1.78 & 0.07 & N.D & N.D & 0.52 & 1.78 & $0.16-1.78$ \\
\hline $\mathrm{Pb}$ & 11.13 & 3.52 & 1.3 & 1.39 & 9.93 & 9.27 & 4.27 & 7.61 & 30.24 & 1.86 & 8.05 & 30.24 & $1.3-30.24$ \\
\hline As & N.D & N.D & N.D & N.D & N.D & N.D & N.D & N.D & N.D & N.D & 0.00 & 0.00 & 0.00 \\
\hline
\end{tabular}


Am. J. Applied Sci., 9 (7): 1014-1019, 2012

Table 5: Result for Baggage Mills zone

Unit 2: The milling shed samples

Code/ Element concentration $\times 10^{4}(\mathrm{ppm})$

\begin{tabular}{|c|c|c|c|c|c|c|c|c|c|c|c|}
\hline Elements & $\mathrm{M}_{1} \mathrm{~S}_{2}$ & $\mathrm{M}_{1} \mathrm{~S}_{3}$ & $\mathrm{M}_{2} \mathrm{~S}_{1}$ & $\mathrm{M}_{2} \mathrm{~S}_{2}$ & $\mathrm{M}_{2} \mathrm{~S}_{3}$ & $\mathrm{M}_{3} \mathrm{~S}_{1}$ & $\mathrm{M}_{3} \mathrm{~S}_{2}$ & $\mathrm{M}_{3} \mathrm{~S}_{3}$ & Mean & Max. & Range \\
\hline$\overline{\mathrm{Al}}$ & 1.32 & 0.53 & 0.74 & N.D & 7.41 & 6.35 & 0.95 & 6.88 & 3.45 & 7.41 & $0.53-7.41$ \\
\hline $\mathrm{Si}$ & 25.60 & 12.61 & 21.16 & 26.17 & 24.76 & 27.33 & 23.64 & 29.33 & 23.83 & 29.33 & $12.61-29.33$ \\
\hline $\mathrm{K}$ & 0.73 & N.D & N.D & N.D & 5.82 & 3.67 & 0.20 & 3.57 & 2.80 & 5.82 & $0.20-5.82$ \\
\hline $\mathrm{Ti}$ & 0.10 & 0.06 & 0.02 & N.D & 0.75 & 0.53 & 0.04 & 0.28 & 0.22 & 0.75 & $0.02-0.75$ \\
\hline $\mathrm{Fe}$ & 7.54 & 6.95 & 5.25 & 3.78 & 7.13 & 14.04 & 52.17 & 11.53 & 13.55 & 52.17 & $3.78-52.17$ \\
\hline $\mathrm{Cu}$ & 0.49 & 0.46 & 0.32 & 0.81 & 0.14 & 0.16 & 0.53 & 0.13 & 0.38 & 0.81 & $0.13-0.81$ \\
\hline $\mathrm{Rb}$ & N.D & 13.71 & N.D & 23.77 & 10.97 & N.D & N.D & N.D & 17.82 & 23.77 & $10.97-23.77$ \\
\hline $\mathrm{Rh}$ & N.D & 0.97 & N.D & 2.59 & N.D & N.D & N.D & N.D & 1.78 & 2.59 & $0.97-2.59$ \\
\hline $\mathrm{Pb}$ & 25.05 & 18.55 & 38.50 & 7.24 & N.D & 2.23 & 31.26 & 1.67 & 17.79 & 38.50 & $1.67-38.50$ \\
\hline As & 0.05 & 0.08 & N.D & N.D & N.D & N.D & N.D & N.D & 0.07 & 0.08 & $0.00-0.05$ \\
\hline
\end{tabular}

Table 6: Result for Baggage sedimentation zone

\begin{tabular}{|c|c|c|c|c|c|c|c|c|c|c|c|}
\hline \multirow[b]{2}{*}{ Element } & \multicolumn{11}{|c|}{$\begin{array}{l}\text { Unit 3: Sedimentation zone } \\
\text { Sample Code/Concentration } \times 10^{4}(\mathrm{ppm})\end{array}$} \\
\hline & $\mathrm{S}_{1} \mathrm{~S}_{1}$ & $\mathrm{~S}_{1} \mathrm{~S}_{2}$ & $\mathrm{~S}_{1} \mathrm{~S}_{3}$ & $\mathrm{~S}_{2} \mathrm{~S}_{1}$ & $\mathrm{~S}_{2} \mathrm{~S}_{2}$ & $\mathrm{~S}_{2} \mathrm{~S}_{3}$ & $\mathrm{~S}_{3} \mathrm{~S}_{2}$ & $\mathrm{~S}_{3} \mathrm{~S}_{3}$ & Mean & Max. & Range \\
\hline $\mathrm{Al}$ & 0.48 & 1.59 & 1.43 & 1.43 & 1.01 & 1.16 & 1.11 & 0.95 & 1.15 & 1.59 & $0.48-1.59$ \\
\hline $\mathrm{Si}$ & 10.65 & 31.90 & 17.38 & 21.42 & 15.23 & 25.27 & 29.80 & 26.39 & 22.26 & 31.90 & $10.65-31.9$ \\
\hline K & N.D & 0.56 & 1.41 & 0.26 & 0.56 & N.D & 0.39 & 0.58 & 0.47 & 1.41 & $0.26-1.41$ \\
\hline $\mathrm{Ti}$ & 0.01 & 0.12 & 0.23 & 0.18 & 0.13 & 0.11 & 0.07 & 0.05 & 0.11 & 0.23 & $0.01-0.23$ \\
\hline $\mathrm{Fe}$ & 5.19 & 4.97 & 11.53 & 8.23 & 9.78 & 7.34 & 6.03 & 6.42 & 7.44 & 11.53 & $4.97-11.53$ \\
\hline $\mathrm{Cu}$ & 0.33 & 0.25 & 0.61 & 0.41 & 0.58 & 0.38 & 0.30 & 0.42 & 0.41 & 0.61 & $0.3-0.61$ \\
\hline $\mathrm{Rb}$ & N. D & N. D & N. D & N. D & N. D & N. D & N. D & N. D & - & - & ${ }^{\circ}$ \\
\hline $\mathrm{Rh}$ & N. D & N. D & N. D & N. D & N. D & N. D & N. D & N. D & - & - & - \\
\hline $\mathrm{Pb}$ & 57.60 & 15.77 & 33.49 & 24.72 & 29.69 & 25.97 & 19.48 & 27.18 & 29.24 & 57.6 & $19.48-57.6$ \\
\hline As & N.D & 0.01 & N.D & N.D & N.D & 0.08 & 0.06 & N.D & 0.05 & 0.08 & $0.01-0.08$ \\
\hline
\end{tabular}

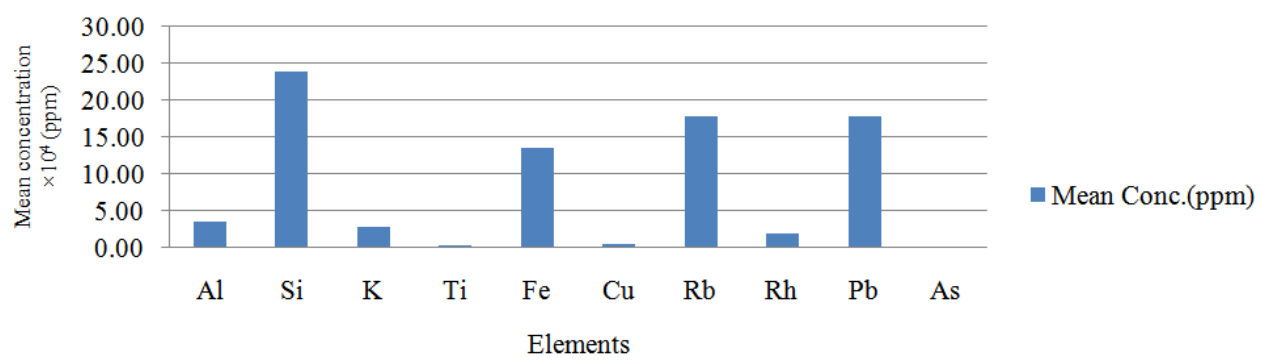

Fig. 5: Chart of result for Bagega mills zone

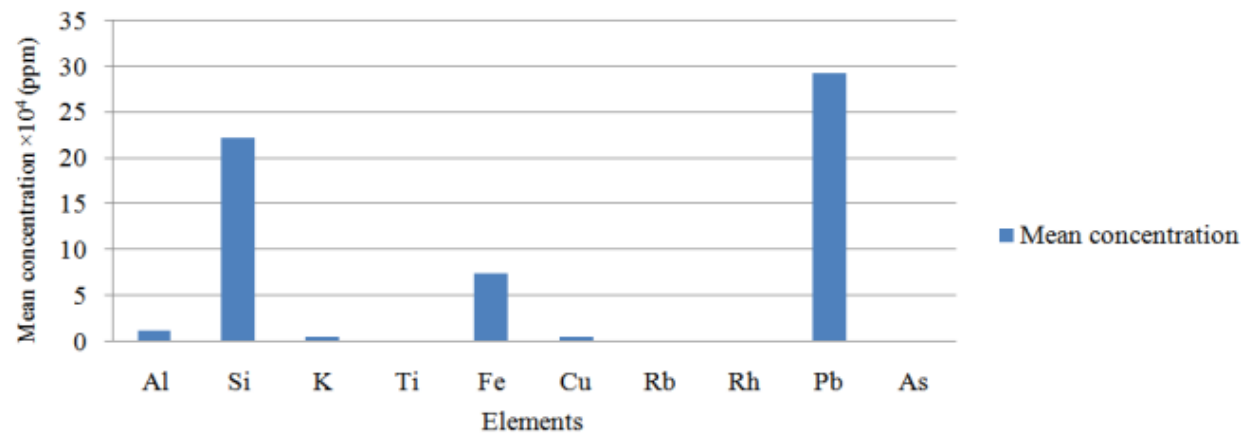

Fig. 6: Chart of result for Bagega sedimentation zone 
Am. J. Applied Sci., 9 (7): 1014-1019, 2012

Table 7a: Percentage composition of mean concentration values of Heavy Metals and other elements of interest from the two study sites Percentage composition of mean values of heavy metals and other elements

\begin{tabular}{|c|c|c|c|c|c|c|c|c|}
\hline \multirow[b]{3}{*}{ Mining stages } & \multirow{2}{*}{\multicolumn{4}{|c|}{$\mathrm{Pb}$}} & \multirow{2}{*}{\multicolumn{2}{|c|}{$\mathrm{Fe}$}} & & \\
\hline & & & & & & & \multicolumn{2}{|l|}{$\mathrm{Rb}$} \\
\hline & Awwal & Bagega & Awwal & Bagega & Awwal & Bagega & Awwal & Bagega \\
\hline Mining zone & 1.75 & 8.05 & 26.32 & 26.87 & 7.80 & 10.20 & 6.27 & 12.16 \\
\hline Milling zone & 2.98 & 17.79 & 39.28 & 23.83 & 8.21 & 13.55 & 8.59 & 17.82 \\
\hline Sedimentation zone & 2.86 & 29.24 & 38.40 & 22.26 & 2.11 & 7.44 & 20.11 & - \\
\hline
\end{tabular}

Table 7b: Converted values of percentage mean concentration values to parts per million (ppm)

\begin{tabular}{|c|c|c|c|c|c|c|c|c|}
\hline \multirow[b]{3}{*}{ Mining stages } & \multicolumn{8}{|c|}{ Parts per million (ppm) composition of mean values of heavy metals concentrations } \\
\hline & \multicolumn{2}{|l|}{$\mathrm{Pb}$} & \multicolumn{2}{|l|}{$\mathrm{Si}$} & \multicolumn{2}{|l|}{$\mathrm{Fe}$} & \multicolumn{2}{|l|}{$\mathrm{Rb}$} \\
\hline & $\begin{array}{l}\text { Awwal } \\
\text { Baggage }\end{array}$ & Baggage & Awwal & Baggage & Awwal & Baggage & Awwal & \\
\hline Mining zone & 17500 & 80500 & 263200 & 268700 & 78000 & 102000 & 62700 & 121600 \\
\hline Milling zone & 29800 & 177900 & 392800 & 238300 & 82100 & 135500 & 85900 & 178200 \\
\hline Sedimentation zone & 28600 & 292400 & 384000 & 222600 & 21100 & 74400 & 201100 & - \\
\hline
\end{tabular}

Table 8: Regulatory limits for comparison to obtained values of Heavy metals and other elements in Table 7b

\begin{tabular}{|c|c|c|c|c|c|c|c|}
\hline \multirow[b]{3}{*}{ Regulatory bodies } & \multicolumn{7}{|c|}{ Regulatory limits } \\
\hline & \multicolumn{2}{|l|}{$\mathrm{Pb}$} & \multirow{2}{*}{$\begin{array}{l}\mathrm{Si} \\
\text { (mean) }\end{array}$} & \multicolumn{2}{|l|}{$\mathrm{Fe}$} & \multicolumn{2}{|l|}{$\mathrm{Rb}$} \\
\hline & (mean) & (range) & & (mean) & (range) & (mean) & (range) \\
\hline Shacklette and Boerngen (1984)* & $19 \mathrm{ppm}$ & $<10-700 \mathrm{ppm}$ & - & $26000 \mathrm{ppm}$ & $100->100,000 \mathrm{ppm}$ & $67 \mathrm{ppm}$ & $<20-210 \mathrm{ppm}$ \\
\hline USEPA Human Health* & $400 \mathrm{ppm}$ & & & $55,000 \mathrm{ppm}$ & & NSL & NSL \\
\hline ACGIH (2004) & & & $3 \mu \mathrm{g} \mathrm{m}^{-3}$ & & & & \\
\hline NIOSH (1974) & - & - & $5 \mu \mathrm{g} \mathrm{m}^{-3}$ & - & - & - & - \\
\hline
\end{tabular}

Key: NSL: No Screening Level; *: Records updated by March 21, 2008

\section{DISCUSSION}

Notable at the two main sites were volumes of dust which ranged in different concentrations from the mining to the processing units. Artisanal miners have been known, from history, as operators without the use of facilities that can provide them with respiratory protection. Thus, with such nature of operations observed in the studied sites, the levels of dust that was observed may be taken as the actual personal exposures of these miners.

The mean concentration value for $\mathrm{Pb}$ is $17.79 \mathrm{mg}$ $\mathrm{Kg}^{-1}$ reaching a maximum concentration of $38.50 \mathrm{mg}$ $\mathrm{Kg}^{-1}$. The value is already at the action level with reference to regulatory limit as shown in Table 8 . Children are known to have developed systems that are vulnerable to toxic elements even at low concentrations. The rise in concentration of $\mathrm{Pb}$ in the milling stage shows that $\mathrm{Pb}$ may be present as well in the mine but its poor mobility may not have allowed its detection on the stage. A comparative assessment of Fig. 4-6 show a trend for $\mathrm{Pb}$; its presence increased with processing stages. There may be possibilities that the solubility of $\mathrm{Pb}$ in the sites is a function of the $\mathrm{pH}$ levels of the soils of each site as well as other accompanying factors.
Considering these properties associated with $\mathrm{Pb}$, they may have worked together in relation to the nature of the soil at the mine location to influence the elevated level of $\mathrm{Pb}$ as well as other elevated concentrations of metals observed in the sedimentation zone. The $\mathrm{Pb}$ results as indicated in Table 7 and 8 showed concentrations well above regulatory benchmark. Children could be exposed largely by their hand-tomouth behaviors, their lower body weight and closeness of their breathing zones to the ground and thus closer to soil contaminants and low-lying layers in the air.

There were four elements all with concentrations several times above regulatory benchmarks in the two Gold mine sites that were studied. Table $7 \mathrm{a}$ shows the percentage composition of mean concentration values of the four elements. The compositions are all shown in parts per million (ppm) in Table $7 \mathrm{~b}$ and Table 8 shows regulatory benchmarks. It can be seen by comparing Table $7 \mathrm{~b}$ and 8 that almost all the elevated elements are in many folds above regulatory benchmarks. All, except $\mathrm{Rb}$, have direct contamination/poisoning properties or possible direct or indirect carcinogenic characteristics. Crystalline Silica is indirectly carcinogenic, while Iron may not be directly poisonous at ordinary state. In its elevated level $\mathrm{Fe}$ essentially stimulates the increase in the 
concentration of other toxicological hazardous elements such as arsenic in soil (Chen et al., 2000).

Of the four high-concentration-elements at various stages, two of them present latent and immediate hazards to health; Respiratory crystalline silica ( $\mathrm{Si}$ ) is the major element constituent of the ever-wellpronounced mining dusts of the two sites. Its form of occurrence portends irreversible health problem called silicosis and is well linked with cancer forming properties; both of which develop through latency periods. Lead $(\mathrm{Pb})$, at any concentration portends both immediate and long term hazards to women and children at the greatest risks of exposures. Consistently high concentrations of respiratory Silica and up surging $\mathrm{Pb}$ in the two sites (especially in Bagega), are signs of possible risk of exposure to contamination/poisoning by these elements.

\section{CONCLUSION}

Based on the work carried out and the results presented, the artisanal gold mining exercises in the two zones are likely to have immediate and long term health risks to the exposed populations if left unchecked. The hazard is not limited to the miners only, but because of the unprofessional practice of the miners, the whole village and its visitors may be equally at risk.

\section{REFERENCES}

ACGIH, 2004. Guide to Occupational Exposure Values. 1st Edn., ACGIH, Cincinnati, ISBN-10: 1882417550, pp: 172.

Balmes, J., M. Becklake, P. Blanc, P. Henneberger and K. Kreiss et al., 2003. Environmental and occupational health assembly. Am. Thoracic Soc.

Chen, M., L.Q. Ma and Y.C. Li, 2000. Concentrations of $\mathrm{P}, \mathrm{K}, \mathrm{Al}, \mathrm{Fe}, \mathrm{Mn}, \mathrm{Cu}$ and $\mathrm{As}$ in Marl Soils from South Cited. In: Heavy Metals and Toxic Trace Elements Contents in Soils of Selected Areas of the Kavala Prefecture, Papastergios, G., (Ed.). Northern Greeceulletin of the Geological Society of Greece, Greece, pp: 263-272.

Chronic Toxicity, 2005. Silica (crystalline, respirable). CAS Registry Number, 7631-86-9.

Glover-Kerkvliet, J., 1995. Environmental assault on immunity. Environ. Health Perspect., 103: 236239. PMID: 7768222
Hnizdo, E. and V. Vallyathan, 2003. Chronic obstructive pulmonary disease due to occupational exposure to silica dust: A review of epidemiological and pathological evidence. Occup. Environ. Med., 60: 237-243. PMID: 12660371

NIH, 1997. Adverse effects of crystalline silica exposure. American thoracic society committee of the scientific assembly on environmental and occupational health. Am. J. Respir Crit Care Med., 155: 761-768. PMID: 9032226

NIOSH, 1974. National Institute for Occupational Safety and Health. NIOSH.

Oxman, A.D., D.C. Muir, H.S. Shannon, S.R. Stock and E. Hnizdo et al., 1993. Occupational dust exposure and chronic obstructive pulmonary disease. A systematic overview of the evidence. Am. Rev. Respir. Dis., 148: 38-48. PMID: 8317812

Park, R., F. Rice, L. Stayner, R. Smith and S. Gilbert et al., 2002. Exposure to crystalline silica, silicosis and lung disease other than cancer in diatomaceous earth industry workers: A quantitative risk assessment. Occup. Environ. Med., 59: 36-43. PMID: 11836467

Popescu, I.V., C. Stihi, G.V. Cimpoca, G. Dima and G. Vlaicu et al., 2009 Environmental sample analysis by Atomic Absorption Spectrometry (AAS) and Inductively Coupled Plasma-optical Emission Spectroscopy (ICP-AES). Rom. J. Phys., 54: 741746.

Shacklette, H.T. and J.G. Boerngen, 1984. Element concentrations in soils and other surficial materials of the conterminous United States. USGS.

Vallyathan, V., V. Castraova, D. Pack, S. Leonard and J. Shumaker et al., 1995. Freshly fractured quartz inhalation leads to enhanced lung injury and inflammation. Potential role of free radicals. Am. J. Respir. Crit. Care Med., 152: 1003-1009. PMID: 7663775

WR, 1998: Heavy metals and health. World Resources Institute, Washington, D.C. 